\title{
Medulloblastoma in a calf of the flemish breed
}

\section{Meduloblastoma em bezerro da raça Flamenga}

\author{
Thierry Grima de Cristo ${ }^{1}$; Maicon Gaissler Lorena Pinto ${ }^{2}$; Thaís Coelho Valente ${ }^{3}$; \\ Ana Karina Couto Hack'; Joandes Henrique Fonteque'; Natália Coelho Couto de \\ Azevedo Fernandes ${ }^{5}$; Cinthya dos Santos Cirqueira Borges ${ }^{5}$; \\ Renata Assis Casagrande ${ }^{6 *}$
}

\begin{abstract}
Medulloblastomas are neuroectodermal tumors of embryonic origin developing in cerebellum and spinal cord and have an unusual occurrence. When occurs in cattle, it is observed in neonatal cases, leading to multiple neurological clinical signs. Flemish cattle are considered at risk of extinction and the rare specimens of Brazil are in Lages, Santa Catarina. The case of a two-month-old calf with difficulty to remain in a standing position, imbalance, opisthotonus, strabismus, and broad-based gait is described in this study. The animal was euthanized and the necropsy showed an irregular, whitish pink, and friable mass in the cerebellar vermis region, measuring $5 \times 6 \times 3.8 \mathrm{~cm}$ associated with the dilation of the lateral ventricles, which extended through the interventricular foramen, midbrain aqueduct, and fourth ventricle. Histologically, it presented elongated triangular neuronal cells arranged in a dense sheet that sometimes encircled small areas of neuropil to form Homer-Wright pseudorosettes. These tumor characteristics were compatible with a medulloblastoma. The immunohistochemical (IHC) evaluation of the tumor demonstrated a positive staining for vimentin in neoplastic cells and glial fibrillary acidic protein in neoplastic stromal cells, non-reactive for synaptophysin, and negative for S100 protein and pan-cytokeratin. The histological and topographical characteristics were paramount for determining the medulloblastoma diagnosis and the IHC panel is similar to that observed in other studies. Tumor growth is limited by skull bony structures, allowing determining that the clinical signs expressed by the animal were directly related to the compression of important functional structures due to tumor expansion. Medulloblastoma is an unusual tumor in all animal species, not previously reported in Flemish cattle, and necropsy followed by histopathological examination is essential for diagnosis.
\end{abstract}

Key words: Neoplasm. neuropathology. Central nervous system. Ruminant.

1 Discente, Curso de Doutorado, Programa de Pós-graduação em Ciência Animal, Laboratório de Patologia Animal, Universidade do Estado de Santa Catarina, UDESC, Lages, SC, Brasil. E-mail: thierry.medvet@gmail.com

2 Pesquisador, Empresa de Pesquisa Agropecuária e Extensão Rural de Santa Catarina, EPAGRI, Lages, SC, Brasil. E-mail: maiconpinto@epagri.sc.gov.br

3 Discente, Curso de Mestrado, Programa de Pós-graduação em Ciência Animal, Hospital de Clínicas Veterinárias, UDESC, Lages, SC, Brasil. E-mail: thaaismv@yahoo.com.br

4 Prof., Departamento de Medicina Veterinária, Hospital de Clínicas Veterinárias, UDESC, Lages, SC, Brasil, E-mail: ana.hack@ udesc.br, joandes.fonteque@udesc.brr

5 Pesquisadoras, Núcleo de Anatomia Patológica, Instituto Adolfo Lutz, São Paulo, SP, Brasil, E-mail: nccafernandes@yahoo. com.br, cinthyacirqueira@yahoo.com.br

${ }^{6}$ Prof ${ }^{a}$, Departamento de Medicina Veterinária, Laboratório de Patologia Animal, UDESC, Lages, SC, Brasil, E-mail: casagrande_ vet@yahoo.com.br

* Author for correspondence 


\section{Resumo}

Meduloblastomas são tumores da neuroectoderme com origem embrionária, que se desenvolvem no cerebelo e na medula espinhal com ocorrência incomum. Quando ocorre em bovinos é observado em casos neonatal, levando a múltiplos sinais clínicos neurológicos. Os bovinos da raça Flamenga estão considerados em risco de extinção e os raros exemplares do Brasil estão localizados em Lages, Santa Catarina. Descreve-se o caso de um bezerro com dois meses de idade, apresentando dificuldade para manter-se em estação, desequilíbrio, opistótono, estrabismo e caminhar em base ampla. $\mathrm{O}$ animal foi submetido a eutanásia e na necropsia observou-se na região do vérmis do cerebelo uma massa irregular, rosa esbranquiçada e friável, medindo $5 \times 6 \times 3,8 \mathrm{~cm}$ associado a dilatação dos ventrículos laterais, que prolongava pelo forame interventricular, aqueduto do mesencéfalo e IV ventrículo. Histologicamente, observava células neuronais triangulares alongadas organizadas em um lençol denso, que às vezes circundavam pequenas áreas de neurópilo para formar pseudorosetas de Homer-Wright, estas características do tumor eram compatíveis com um meduloblastoma. A avaliação imuno-histoquímica (IHQ) do tumor demonstrou marcação positiva para vimentina em células neoplásicas e para proteína glial fibrilar ácida em células do estroma neoplásico, não reagente para sinaptofisina e negativo para proteína S100 e pan-citoqueratina. As características histológicas e topográficas foram primordiais para a determinação do diagnóstico de meduloblastoma e o painel IHQ é semelhante à observada em outros trabalhos. O crescimento do tumor é limitado pelas estruturas ósseas do crânio, permitindo determinar que os sinais clínicos expressos pelo animal estavam diretamente relacionados com a compressão de estruturas funcionais importantes em decorrência da expansão tumoral. O meduloblastoma é um tumor incomum em todas as espécies de animais, não relatado até agora em bovinos da raça Flamenga e para o diagnóstico é essencial a realização de necropsia seguida da avaliação histopatológica.

Palavras-chave: Neoplasia. Neuropatologia. Sistema nervoso central. Ruminante.

\section{Introduction}

Neuroectodermal primitive cell tumors constitute a group of embryonal neuroepithelial neoplasms that originate in the supratentorial region in the brainstem and spinal cord. Medulloblastoma is one of the primitive neuroectodermal tumors, with malignant behavior and cerebellar topography, whose denomination is closely related to its anatomical origin since there are no cells called "medulloblasts" among precursors of nervous tissue (HIGGINS et al., 2017).

It is a relatively common tumor in children, but uncommon in domestic animals. In several animal species, this tumor occurs in middle and old age, but in cattle, it is commonly observed in neonatal cases such as in humans (HIGGINS et al., 2017). Clinical changes intrinsic to the tumor in animals may be single or multiple, ranging from postural changes to convulsions, changes in mental status, paresis and facial palsy, head swaying, strabismus, nystagmus, and hyporeflexia. The intracranial surgical approach is complex and expensive, requiring nursing care that makes the treatment infeasible (SMITH; GEORGE, 2009).

Flemish cattle are part of one of the oldest breeds of France, with a dual aptitude, being distinguished by the milk production. This is a breed considered to be in danger of extinction (FAO, 2000) and in Brazil, the specimens are concentrated only at the Experimental Station of the Company of Agricultural Research and Rural Extension of Santa Catarina (EPAGRI) in Lages, Santa Catarina. Constant researches are carried out with these animals to improve the reproductive and productive indices and thus be able to perpetuate them (GOETTEN, 2013).

The aim of this study is to describe the clinical and pathological changes of a medulloblastoma in a calf of the Flemish breed. 


\section{Case Report}

The case described was of a two-month-old male Flemish calf, from the herd of EPAGRI, Lages, SC. The animal presented a history of difficulty to remain in the quadrupedal position, constant stay in lateral or sternal recumbency, motor incoordination, opisthotonus, and palpebral tremor with beginning 15 days before being admitted at the Hospital of Veterinary Clinics (HCV) of the Agro-veterinary Sciences Center (CAV) of the State University of Santa Catarina (UDESC). The neurological examination showed an depression, posture and abnormal coordination of head characterized by opisthotonus when in lateral recumbency, and bilateral dorsomedial strabismus (Figure 1). The animal was able to remain in the quadrupedal position only with support, broad-based supported with the thoracic limbs, and with constant imbalances and spontaneous falls. When forced to walk, it demonstrated a bilateral symmetrical ataxia, with no signs of paresis or proprioceptive deficit, and an increased muscle tone in the pelvic limbs. Cerebrospinal fluid was collected from the cisterna magna, which showed a low ejection force of the fluid during drainage, preventing the production of a jet, but showing a high frequency of dripping, suggesting a possible increase of intracranial pressure. The obtained liquor did not present significant alterations during physical, cytological, and biochemical evaluation. Blood samples were collected for blood counts and serum biochemistry, with no significant changes. Serum was used for an immunoenzymatic assay for bovine viral diarrhea virus (BVDV), which was positive, Neospora caninum, and infectious bovine rhinotracheitis, both negative.

Figure 1. Medulloblastoma in a male, two-month-old Flemish calf.
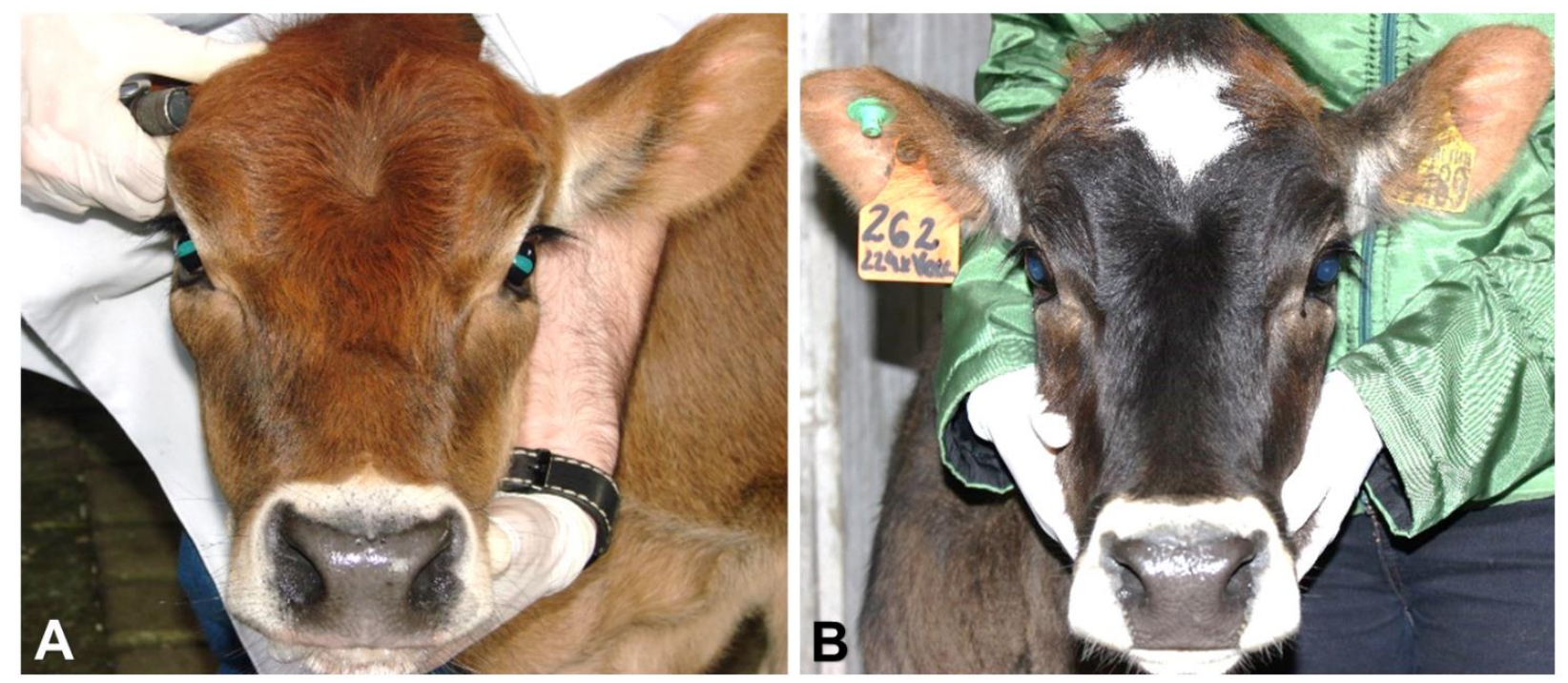

A. Injury in the fourth pair of cranial nerves, with bilateral dorsomedial strabismus. B. To compare, animal with eyes in normal position.

The main clinical suspicions included polioencephalomalacia, neosporosis, cerebellar hypoplasia (by BVDV), herpetic meningoencephalitis (bovine herpesvirus type 5), and cerebral abscess. A clinical treatment based on dexamethasone ( $4 \mathrm{mg} / \mathrm{kg}$ SID IM for $5 \mathrm{~d}$ ) and thiamine
(20 mg/kg SID IM for $5 \mathrm{~d}$ ) was instituted. The animal was hospitalized in the HCV for nine days, with no clinical improvement after treatment. Due to frequent falls and inability to remain in a standing position, the animal developed decubitus sores in the iliac and ischiatic tuberosity region, bilaterally. 
Due to insufficient clinical improvement in response to therapeutic interventions and impossibility of maintaining the patient in perfect welfare, the euthanasia was chosen and performed by administration of $2 \%$ xylazine hydrochloride $(0.2 \mathrm{mg} / \mathrm{kg}$ IV $)$ followed by anesthetic induction with $10 \%$ ketamine hydrochloride (3mg/kg IV) and potassium chloride diluted to $19 \%(70 \mathrm{mg} / \mathrm{kg} \mathrm{IV})$. The animal was sent to the Laboratory of Animal Pathology of CAV-UDESC for necropsy.
During the opening of the cranial bone, a large amount of translucent liquid was observed draining from the foramen magnum. An irregular, whitish pink, and extremely friable mass measuring $5 \times 6 \times 3.8 \mathrm{~cm}$ was observed in the cerebellar vermis region (Figure 2A). The telencephalon cut showed a dilation of the lateral ventricles, which extended through interventricular foramen, midbrain aqueduct, and fourth ventricle.

Figure 2. Anatomopathological and immunohistochemical features of medulloblastoma.
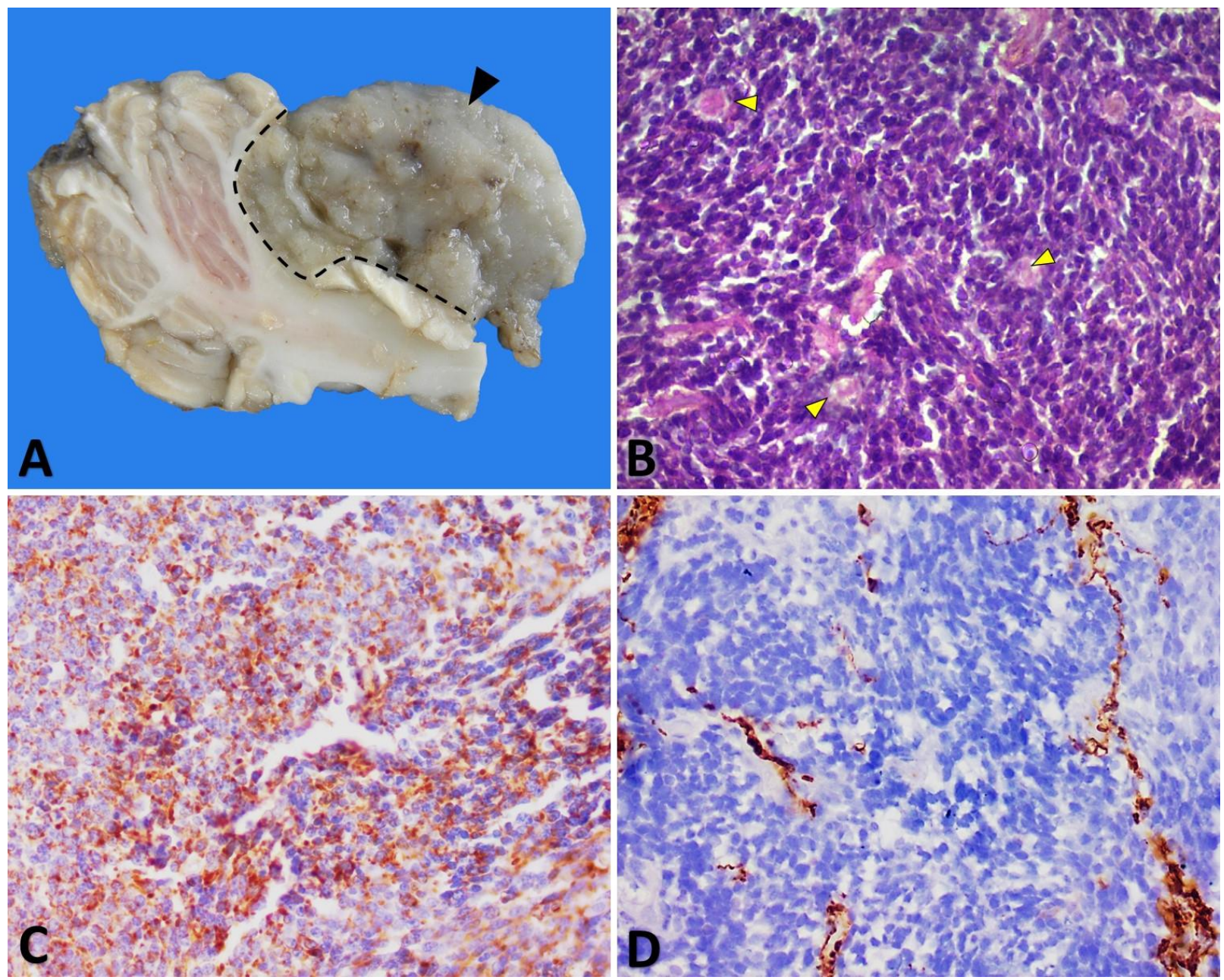

A. Macroscopic aspect of the tumor. Friable and irregular mass, expanding the neuropil ventrally and projecting from the cerebellar vermis (arrowhead, delimited by the black dash). B. Histopathological appearance of the tumor. Evidence of HomerWright pseudorosettes filled with neuropil remnants (arrowheads), formed by triangular and elongated neuronal cells (HE, 400x). C. Positive and diffuse immunohistochemical reaction for vimentin in neoplastic cells (endogenous peroxidase-bound polymer, DAB chromogen, 400x). D. Positive and diffuse immunohistochemical reaction for GFAP in neoplastic stroma cells (endogenous peroxidase-bound polymer, DAB chromogen, 400x). 
Fragments of all organs were collected, conditioned in $10 \%$ buffered formaldehyde, and submitted to the routine histological processing and hematoxylin and eosin (HE) staining. Brain, cerebellum, and tumor mass fragments were frozen to carry out the polymerase chain reaction (PCR) for $N$. caninum using as a target the sequence Nc5Np21plus/Np6plus, which was negative. The total blood sample was frozen for reverse transcription reaction followed by BVDV polymerase chain reaction (RT-PCR) by the detection of a 119 bp fragment of the pestiviral 5'-UTR region (WEBER et al., 2014), which also was negative.

The histopathological evaluation of the cerebellum showed a malignant, non-delimited neoplastic proliferation, composed of elongated triangular neuronal cells (carrot-shaped cells) arranged in a dense sheet consisting of bundles that went through multiple directions and were supported by a discrete fibrovascular stroma. The nucleus of these cells was rounded to oval, sometimes hyperchromatic, sometimes discretely vesiculous with one to three evident nucleoli and a scarce and slightly eosinophilic cytoplasm. About three mitotic figures out of 10 fields of higher magnification (40x) were observed. In some areas, cell groups were observed surrounding areas of hypereosinophilic neuropil and forming Homer-Wright pseudorosettes (Figure 2B).

The immunohistochemical (IHC) evaluation was performed at the Pathology Center of the Adolfo Lutz Institute in São Paulo, SP. Histological sections of medulloblastoma were submitted to the search for synaptophysin (SY38, Agilent/Dako Cytomation, Carpinteria, CA, USA), S100 protein (Polyclonal, Agilent/ Dako Cytomation, Carpinteria, CA, USA), pan-cytokeratin (clone cocktail AE1+AE3, Biocare, Pacheco, CA, USA), glial fibrillary acidic protein (GFAP; GA-5 clone, Biogenex, Fremont, CA, USA), and vimentin (V9 clone, Invitrogen/ Thermofisher Scientific, Rockford, IL, USA) with the use of the technique of polymer conjugated with the enzyme peroxidase and secondary antibodies
(Novolink, Leica Biosystems, Newcastle, UK) and developing with the chromogenic substrate diaminobenzidine (DAB, Merck/Sigma Aldrich, St. Louis, MO, USA). There was a diffuse labeling for vimentin in neoplastic cells (Figure 2C) and diffuse for GFAP in stromal cells (Figure 2D). No reactivity was observed for synaptophysin in neoplastic cells or neurons in the neighboring nervous tissue. The other reactions did not express labeling.

\section{Discussion}

After an exhaustive search in databases and journal compilation, rare detailed reports were found for medulloblastomas in cattle (FANKHAUSER et al., 1982; BIANCHI et al., 2015). In Brazil, there is only one report documented by Silva et al. (2015) in an animal of the Girolando breed. However, to date, no cases have been described in Flemish cattle. Considering the small number of residual individuals of the Flemish breed, it is known that the reproductive management for breed recovery involves parental cross, but the relation of consanguinity with the development of medulloblastoma in cattle has not yet been explored, and thus its involvement cannot be discarded for the formation of these tumors.

Tumors originating from primordial cells of the neuroectoderm (more precisely neuroblastoma and medulloblastoma) have very similar characteristics, making determinant the association between anatomical location of the neoplasm and their respective histological characteristics, which include Homer-Wright pseudorosettes and atypical triangular neuronal cells (carrot-shaped cells), criteria that are essential for the final diagnosis (FANKHAUSER et al., 1982; SILVA et al., 2015).

Positive labeling of IHC for vimentin in neoplastic cells and for GFAP in glial cells is like that observed in other studies (BIANCHI et al., 2015; SILVA et al., 2015; HIGGINS et al., 2017). Although the majority of neuroectodermal tumors are positive for synaptophysin and S100 protein, 
studies in humans have pointed out that this positivity is not ubiquitous (MEURER et al., 2008). In addition, IHC labeling of these tumors in cattle and other animal species can be highly variable, reacting or not with neoplastic cells, mainly due to the distinction between the molecular structure of the antibody, originally designed for humans, and target antigens in tissues of the species in question (STEINBERG et al., 2006; HIGGINS et al., 2017). Thus, the absence of positivity and the absence of IHC reactivity for the markers agreed with human medicine does not allow excluding medulloblastoma as a definitive diagnosis.

Neurological signs in cattle may represent several different diseases of courses and etiologies, but for the animal in question, diseases specific to age, which included necrotizing encephalitis by $N$. caninum, cerebellar hypoplasia due to BVDV infection, and herpetic meningoencephalitis, were investigated (SMITH; GEORGE, 2009). In addition to the histological changes demonstrated by tumor expansion, no indication of encephalitis, meningoencephalitis, and cerebellar hypoplasia was observed in this animal.

The use of RT-PCR to determine the definitive diagnosis of BVDV did not confirm the previous serological diagnosis. Serological tests have their value during the evaluation of vaccine efficacy, adherence to the vaccination protocol, and exposure to BVDV (SALIKI; DUBOVI, 2004), but they should not be considered as determinants for the institution of the final diagnosis, mainly as a result of high levels of maternal antibodies in animals aged less than three months, which can induce both falsenegative and false-positive results, as observed in this animal (HILBE et al., 2007). In addition, the morphological alterations associated with BVDV are commonly hydrocephalus, hydranencephaly, porencephaly, microcephaly, and cerebellar hypoplasia, which would determine macroscopically an encephalon with dilated ventricles and with less functional brain and cerebellar tissue and occasional cystic formations filled by cerebrospinal fluid in the neuropil, and histology shows edema, hemorrhage, and perivascular inflammation, with consequent necrosis of cells of the granular layer of the cerebellum and in Purkinje cells (AGERHOLM, 2015). Despite hydrocephalus, as a consequence of tumor compression, none of the other alterations were observed macro or microscopically, which makes it even more feasible to disassociate the BVDV to the case.

As described in other reports, postural alterations of appendices and head were strong indications of a cerebellar lesion (BIANCHI et al., 2015; SILVA et al., 2015). The clinical changes evidenced are intrinsic to the location of the tumor, whose expansion is hampered by the bone structural conformation of the skull, tentorium, and cerebellar sickle (SMITH; GEORGE, 2009). This compressive tumor expansion also explains the low pressure in the liquor flow during the drainage of the cisterna magna, indicating an obstruction of pathways of the ventricular system, reducing the ejection force of liquor, but with an intense drip, indicating an increased intracranial pressure.

The limitation imposed to the neoplasm expansion results in morphological changes of adjacent structures, including a compression of the nucleus of the trochlear nerve (IV) on the dorsal surface of the midbrain, leading to the bilateral dorsomedial strabismus, compression of blood vessels, and obstruction of the fourth ventricle, leading to malacia in areas adjacent to the tumor and hydrocephalus observed during necropsy (BIANCHI et al., 2015).

\section{Conclusion}

Medulloblastoma is a tumor of the nervous system little reported and uncommon in animals, not yet reported in Flemish cattle. It is a neoplasia with a very aggressive clinical course, besides a difficult and costly diagnosis in vivo. Because it 
is reported as a postmortem finding, it is essential to perform necropsy followed by histopathological evaluation of animals with tumors in the nervous system to determine the definitive diagnosis of this neoplasm in cattle.

\section{Acknowledgments}

To Cristina Takami Kanamura of the Adolfo Lutz Institute, São Paulo, SP, for the support in performing the immunohistochemical analyses. To Professor Cláudio Wageck Canal of the Laboratory of Virology FaVet/UFRGS for carrying out RTPCR for BVDV and to the doctor Hilda Fátima de Jesus Pena of the Laboratory of Parasitic Diseases of VPS-FMVZ/USP for carrying out the PCR of $N$. caninum.

\section{References}

AGERHOLM, J. S.; HEWICKER-TRAUTWEIN, M.; PEPERKAMP, K.; WINDSOR, P. A. Virus-induced congenital malformations in cattle. Acta Veterinaria Scandinavica, London, v. 57, n. 1, p. 1-14, 2015. DOI: 10.1186/s13028-015-0145-8

BIANCHI, E.; BOMBARDI, C.; BASSI, P.; BOLCATO, M.; GENTILE, A.; MILITERNO, G. Bilateral trochlear nerve palsy as a consequence of cerebellar medulloblastoma: Clinical and pathological findings in a calf. Journal of Veterinary Internal Medicine, Philadelphia, v. 29, n. 4, p. 1117-1121, 2015. DOI: 10.1111/jvim. 13568

FANKHAUSER, R.; FATZER, R.; HERMANN, M. Medulloblastome bei verschiedengeschlechtigen Zwillingskälbern. Schweizer Archiv fur Tierheilkunde, Zürich, v. 124 , n. 7 , p. 363-367, 1982. DOI: $10.5169 /$ seals-588251

FOOD AND AGRICULTURE ORGANIZATION OF THE UNITED NATIONS - FAO. World watch list for domestic animal diversity. $3^{\text {th }}$ ed. Rome: FAO, 2000. 726 p.

GOETTEN, A. L. F. Flamenga, uma raça em extinção: caracterização do desenvolvimento folicular de bovinos da raça flamenga no sul do Brasil. 2013. Dissertação (Mestrado em Ciência Animal) - Centro de Ciências Agroveterinárias, Universidade do Estado de Santa Catarina, Lages.
HIGGINS, R. J.; BOLLEN, A. W.; DICKINSON, P. J. Nervous system. In: MEUTEN, D. J. (Ed.). Tumors in domestic animals. $5^{\text {th }}$ ed. Iowa: John Wiley \& Sons, 2017. p. 834-891.

HILBE, M.; PETERHANS, E.; HAESSIG, M.; NUSSBAUMER, M.; EGLI, C.; SCHELP, C.; ZLINSZKY, K.; EHRENSPERGER, F. Comparison of five diagnostic methods for detecting bovine viral diarrhea virus infection in calves. Journal of Veterinary Diagnostic Investigation, Columbia, v. 19, n. 1, p. 28-34, 2007. DOI: $10.1177 / 104063870701900105$

MEURER,R.T.;MARTINS,D.T.;HILBIG,A.;RIBEIRO, M. C.; ROEHE, A. V.; BARBOSA-COUTINHO, L. M.; FERNANDES, M. C. Immunohistochemical expression of markers KI-67, NeuN, synaptophysin, p53 and HER2 in medulloblastoma and its correlation with clinicopathological parameters. Arquivos de NeuroPsiquiatria, São Paulo, v. 66, n. 2 B, p. 385-390, 2008. DOI: $10.1590 / \mathrm{S} 0004-282 X 2008000300020$

SALIKI, J. T.; DUBOVI, E. J. Laboratory diagnosis of bovine viral diarrhea virus infections. Veterinary Clinics of North America - Food Animal Practice, Philadelphia, v. 20, n. 1, p. 69-83, 2004. DOI: 10.1016/j.cvfa.2003.11.005

SILVA, R. J.; AFONSO, J. A. B.; MENDONÇA, C. L.; DANTAS, A. C.; GUIMARÃES, J. A.; DANTAS, A. F.; TORRES, M. B. A. M.; KOMMERS, G. D. Medulloblastoma in a calf: case report. Brazilian Journal of Veterinary Pathology, São Paulo, v. 8, n. 1, p. 29-32, 2015.

SMITH, M. O.; GEORGE, L. W. Diseases of the nervous system. In: SMITH, B. P. (Ed.). Large animal internal medicine. $4^{\text {th }}$ ed. Saint Louis: Mosby, 2009. p. 972-1111.

STEINBERG, H.; PEEK, S. F.; NELSON, K. M. Neuroblastoma with neuronal differentiation in the spinal cord in an Aberdeen Angus heifer calf. Veterinary Pathology, Thousand Oaks, v. 43, n. 2, p. 193-7, 2006. DOI: $10.1354 /$ vp.43-2-193

WEBER, M. N.; SILVEIRA, S.; MACHADO, G.; MÓSENA, A. C.; BUDASZEWSKI, R. F.; DUPONT, P. M.; COBELLINI, L. G.; CANAL, C. W. High frequency of bovine viral diarrhea virus type 2 in Southern Brazil. Virus Research, Amsterdam, v. 191, p. 117-24, 2014. DOI: $10.1016 /$ j.virusres.2014.07.035 
